\title{
Microwave Fixation in Rat Fetuses Tissues: Histological and Immunohistochemical Analysis
}

\author{
Fijación de tejidos de Fetos de Ratas por Microondas: Análisis Histológico e Inmunohistoquímico
}

\author{
"Dimitrius Leonardo Pitol; ***João Paulo Mardegan Issa; "Eduardo Camacho; \\ **Nilce de Oliveira Wolga: "Flávio Henrique Caetano \& ** Laurelúcia Orive Lunardi
}

PITOL, D. L.; ISSA, J. P. M.; CAMACHO, E.; WOLGA, N. O.; CAETANO, F. H. \& LUNARDI, L. O. Microwave fixation in rat fetuses tissues: Histological and immunohistochemical analysis. Int. J. Morphol., 25(4):695-701, 2007.

SUMMARY: The aim of this study was to show the microwaves action in fixation of rat fetuses, dermal and cartilaginous tissues, using histological and immunohistochemistry methods for analysis. It was possible to conclude in this study using the rat as experimental model that the two methods for antibody retrieval, presented an excellent ways for the use of Ki67 antibody in the immunohistochemical analysis.

KEY WORDS: Microwave; Rat; Histological and immunohistochemical analysis; Fixation.

\section{INTRODUCTION}

Conventional immersion fixation is the most frequently used method that can take from several hours up to several weeks (Clarke, 1974; Clark, 1985, 1991; Jurvelin et al., 1983; Jeffrey et al., 1991). Long periods of fixative penetration are usually required; this can cause time-dependent artifacts such as shrinkage and extraction of cellular components. Also, for large specimens $\left(1 \mathrm{~cm}^{3}\right)$, gradients in the quality of fixation through the specimen occur from an overfixed surface to underfixed internal tissue.

Cryofixation and ensuing freeze-substitution at ambient (Nötzli \& Clark, 1994) or high pressure (Hunziker \& Schenck, 1984; Keene \& McDonald, 1993; Engfeldt et al., 1994) is possible. Cryofixation followed by freeze drying has also been performed (Draenert \& Draenert, 1982). However, with the first and third methods crystallization artifacts of this highly aqueous tissue are limiting for fine structure analysis (Echlin, 1991). This can be overcome by high-pressure freezing, but here the maximum depth of vitrification, ice crystal-free fixation, is $150 \mu \mathrm{m}$ (Studer et al., 1995).

Microwave techniques have been applied successfully in pathology and morphological studies (Boon \& Kok 1986,
1987) for fixation, staining, histoprocessing and immunohistochemistry (Boon et al., 1988). Surveys of the fundamentals of microwave-stimulated staining are available (Boon \& Kok 1986, 1987).

A major goal of fixation is to stabilize the proteins. This can be achieved without using chemicals simply by utilizing the heat generated by microwave irradiation (Mayers, 1970). Microwave-irradiation-enhanced fixation has fewer sample size limitations than freeze fixation, up to dimension of $1 \mathrm{~cm}^{3}$ (Johnson \& Guy, 1972). It also minimizes long-term fixation artifacts such as extraction of cellular components, and has no crystallization problems. Microwave irradiation stimulates fixative diffusion and enhances reaction rates, causing internal heating. By simultaneously affecting the complete tissue block, it is able to heat within the sample, thereby avoiding time-dependent gradients of fixation (Jones $\&$ Stavinoha, 1979). The increased temperature coagulates and precipitates the proteins and the microwaves stabilize the proteins non-covalent secondary bonding (Leong, 1988). During aldehyde fixation, the irradiation changes the polymers to monomers, which increases diffusion and enhances chemical bonding to the proteins (Chew et al., 1983). The irradiation shortens the diffusion time of fixatives

\footnotetext{
* Biosciences Institute- Molecular and Cellular Biology (UNESP), Rio Claro, São Paulo, Brazil.
}

${ }^{* *}$ Faculty of Dentistry of Ribeirão Preto, University of São Paulo, São Paulo, Brazil. 
into the tissue and accelerates the chemical processes involved in fixation (Hopwood et al., 1988).

During the development of the use of microwaves enhanced fixation many useful additions have been made. A short time lapse between death and fixation is valuable for preservation of a near to natural state (Boon \& Kok, 1988). High energy levels absorbed by the tissue can destroy membranes, but the damage can be prevented by the use of a water load as a heat sink (Login \& Dvorak, 1985). Reproducibility of fixation is also improved with a heat sink (Login \& Dvorak, 1993). For good ultrastructural images the tissue should be removed immediately after irradiation and placed in a cold buffer solution (Login et al. 1986). There is very slow irradiation measured at depths greater than $1 \mathrm{~cm}$ from the sample surface and so small volumes surrounding the tissue should be used (Wickersheim et al., 1990).

Thus, the aim of this study was to show the microwaves action in fixation of rat fetuses' tissue, using histological and immunohistochemistry methods for analysis.

\section{MATERIAL AND METHOD}

All the aspects of this study were approved by Ethics Committee of University of São Paulo, Brazil. It was used five Wistar rat fetuses samples composed by dermal and cartilaginous tissues, the first group was immersed in $4 \%$ paraformaldehyde during 72 hours; the second group was immersed in $4 \%$ paraformaldehyde and irradiated using a microwave oven (PANASONIC) during 1 minute and removed 10 minutes later, according to Login et al., method, for histological processing. After, the fetuses were included in paraffin (Merck) and cut of into $6 \mu \mathrm{m}$ using silanized histological glasses. The histological samples were stained by sodium acetate giemsa, hematoxilin-eosin and mallory trichrome.

For immunohistochemical analysis, it was used histological glasses composed by fetuses samples fixed in microwave oven, which were divided into three groups, in the first group it was performed the antigenic retrieving soaking the histological glasses in sodium citrate solution pH6.0, during 40 minutes; the second group was immersed in sodium citrate solution $\mathrm{pH} 6.0$ and irradiated in a microwave oven during 2 minutes in maximal temperature; in the third group, it was performed the immuno-histochemical analysis without doing the antigenic retrieving. For this immunohistochemical analysis, it was used the Ki67 antibody (Novocastra), recommended in the evaluation of the cellular proliferation. The antibody dilution was $1 / 200 \mu \mathrm{L}$, incubated by 60 minutes and exposed using the ABC kit, Novocastra.

\section{RESULTS}

The dermal tissue samples stained by Giemsa showed a better preservation of the connective tissue in the fixative procedure. When the dermal tissue samples were stained by Mallory trichrome, the epithelial tissue and corneous layer showed a better preservation when fixed in microwave oven. The cartilaginous tissue stained by showed a significant difference (Fig.1). When the immunohistochemical analysis was performed in fetuses, it was possible to observe a strongly staining using Ki67 in the epithelial cells samples retrieved by steamer and with microwave oven (Fig. 2).

In relation to fixative process, our results showed an advantage fixing using microwave oven, being possible to affirm that the microwave oven can accelerate the histological processing of the samples, without compromising the tissue structures. Thus, it is possible to obtain immunohistochemical reactions with a better quality and more confiable, however, in the histological glasses that it was applied immunohistochemical reaction without antigenic retrieval, it was not possible to detect immunohistochemical reaction for Ki67 antibody (Figs. 1 and 2).

\section{DISCUSSION}

This study presents the microwaves action in fixation of rat fetuses' tissue, using histological and immunohistochemistry methods for analysis. Microwave fixation, alone or combined with aldehydes, gave excellent preservation of morphological detail and antigenicity was retained in a wide variety of tissues, as it was observed in this study. In addition, when specimens were fixed by microwave irradiation in aldehydes it was possible to reduce the concentration of the primary antibodies by tenfold compared with conventionally fixed material and still to achieve excellent immunostaining. More over, it was not possible to stain for keratin in the epithelium of formalinfixed skin, although specimens fixed by microwave irradiation stained well (Login \& Dvorak, 1985). For light microscopy, microwave fixation has been shown to have an advantage over conventional fixation for immunohistochemistry.

The demand for a rapid and reproducible fixation for cartilaginous and dermal tissues have been addressed by the application of microwave enhanced fixation and staining. The application of microwave irradiation between 


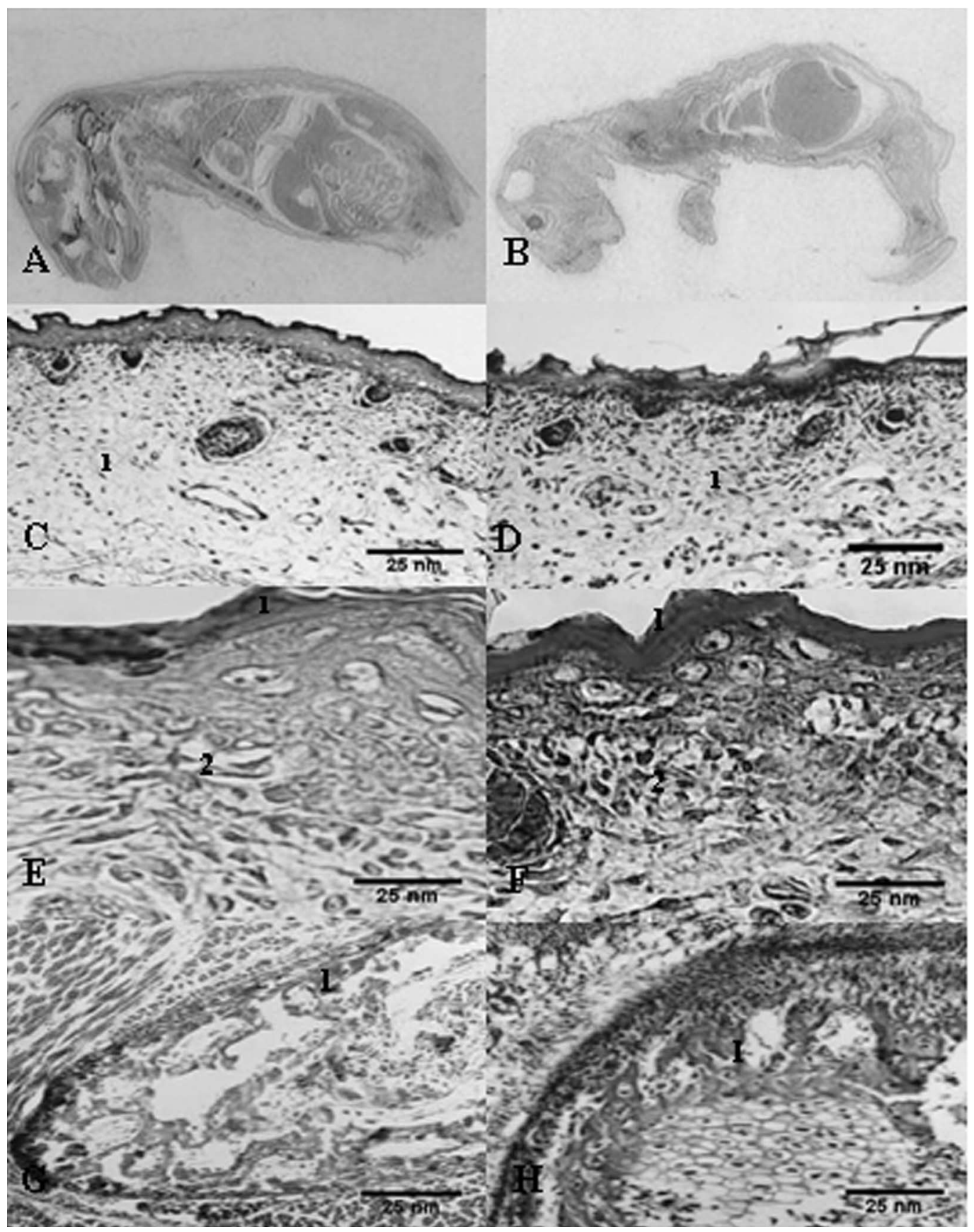

Fig. 1. A. Photomicrograph showing fetuses tissue fixed by formol during 72 hours (Hematoxilin-Eosin stain).

B. Photomicrograph showing fetuses tissue fixed in microwave oven during 1 minute.

C. Photomicrograph showing fetuses tissue fixed by formol during 72 hours. The dermal tissue stained by Giemsa shows a bad fixation of the connective tissue (1) (100x of original magnification).

D. Photomicrograph showing fetuses tissue fixed in microwave oven and stained by Giemsa. Good fixation of the connective tissue (1) (100x of original magnification).

E. Photomicrograph showing fetuses tissue fixed by formol during 72 hours (Masson Trichrome stain). Good fixation of the corneous layer (1) and connective tissue (2) (100x of original magnification).

F. Photomicrograph showing fetuses tissue fixed in microwave oven and stained by Mallory Trichrome. Very good preservation of the corneous layer (1) and connective tissue (2) (100x of original magnification).

G. Photomicrograph showing fetuses tissue fixed by formol during 72 hours (Mallory Trichrome stain). Bad preservation of the cartilaginous tissue (1) (100x of original magnification).

H. Photomicrograph showing fetuses tissue fixed in microwave oven during 1 minute and stained by Mallory Trichrome. Good preservation of the cartilaginous tissue (1) (100x of original magnification). 


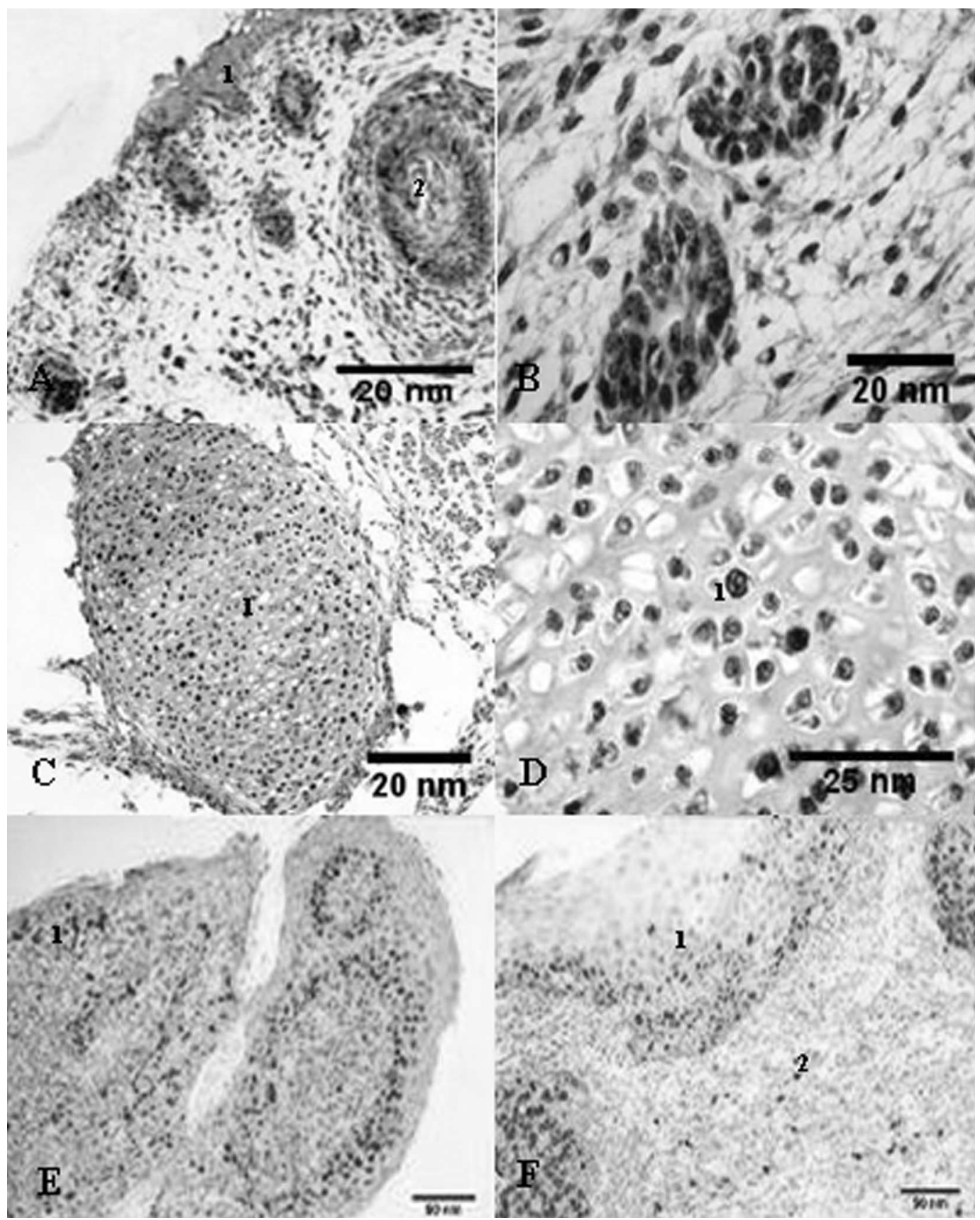

Fig. 1A. Photomicrograph showing fetuses tissue fixed in microwave oven and antigenic retrieval for immunohistochemical analysis. (1) Antibody Ki67 staining epithelial cells. (2) Antibody Ki67 staining folliculus pili (100x of original magnification). B. Photomicrograph showing fetuses tissue fixed in microwave oven and antigenic retrieval for immunohistochemical analysis. Antibody Ki67 staining folliculus pili cells (400x of original magnification).

C. Photomicrograph showing fetuses tissue fixed in microwave oven during 1 minute and antigenic retrieval with steamer for immunohistochemical analysis. (1) Antibody Ki67 staining cartilaginous cells (100x of original magnification).

D. Photomicrograph showing fetuses tissue fixed in microwave oven during 1 minute and antigenic retrieval with steamer for immunohistochemical analysis. (1) Antibody Ki67 staining cartilaginous cells (400x of original magnification).

E. Photomicrograph showing fetuses tissue fixed in microwave oven during 1 minute and antigenic retrieval with steamer for immunohistochemical analysis. (1) Antibody Ki67 staining epithelial cells, (2) Antibody Ki67 staining connective cells (100x of original magnification).

F. Photomicrograph showing fetuses tissue fixed in microwave oven and antigenic retrieval for immunohistochemical analysis. (1) Antibody Ki67 staining epithelial cells, (2) Antibody Ki67 staining connective cells (100x of original magnification). 
303 and $313 \mathrm{~K}$ allows excellent preservation of cartilage structure. At $333 \mathrm{~K}$ heat damage can be observed. This agrees with work by Visser et al., 1992. They observed that treatment of dermal sheep collagen with $0.65 \%$ glutaraldehyde and microwave irradiation at $333 \mathrm{~K}$ resulted in maximum shrinkage within 1 minute, compared with small amounts of shrinkage at lower temperatures. However, no loosening of the cartilage from the subchondral shrinkage bone, caused by heating of the minerals in the bone, has been observed. The temperatures measured were from the surrounding fixative solutions as the temperatures generated inside the sample could not be measured.

The time of fixation should be minimal to prevent extraction and shifting of diffusible ions and molecular components. The duration of the microwave fixation was 1 minute. This is much faster than any conventional soaked method used (Jurvelin et al.; Clark, 1991). During fixation and subsequent dehydration, the tissue can shrink by up to 50 vol.\%. Gilmore \& Palfrey (1987) observed just such a high shrinkage of cartilage tissue. The results obtained in our data showed shrinkage of less than $30 \%$ in total for the conventional method and as low as $20 \%$ for microwave fixation. This shows that microwave method does not increase the overall amount of shrinkage preparation. The fat that concealed detail on various samples when using all methods comes from the subchondral bone, removal of which is under current investigation.

Diffusion of fixative is, generally, faster than the chemical reaction of the fixative with the tissue. As a result, concentric zones form in the tissue as fixation progresses. An ordinary kitchen oven provides external heating and promotes fixation of the outer margins of the tissue. It is this chemical fixation that forms a barrier preventing the fixative from penetrating deeply (Drury \& Wallington, 1967; Hopwood, 1982) and, paradoxically, decreases the rate of fixation. Irradiation in a microwave oven generates internal heating in the central zone of the tissue causing an increase in the rate of fixative penetration. This phenomenon is called microwave stabilization and is defined as the fixation brought about exclusively by the radiation effect of a microwave oven without using a chemical reagent. By contrast, chemical fixation stimulated by microwaves, refers to fixation produced by any chemical reagent in a microwave oven (Kok \& Boon, 1990b; Hopwood et al., 1984; Boon et al., 1988; Login \& Dvorak, 1988). During microwave irradiation, a zone forms between the chemical fixation facilitated externally by a microwave and fixation that occurred internally by microwave stabilization (Horobin \& Flemming, 1990).
The cryofixation, entailing freezing at ambient pressure followed by freeze-substitution, allowed a rapid preservation of the initial state within seconds, bit the ensuing fixation with the chemical substitution took several days. The cryofixation was seen to preserve sample sizes up to $12 \times 3 \mathrm{~mm}$, but the unavoidable introduction of ice-crystal artifacts for such a large sample size destroyed the cell structures. In some samples gaps also occurred between the collagen fibers. In recent works, for the fixation of whole joints, the modified method has removed this problem.

Conventional fixation showed good results comparable with microwave fixation below $323 \mathrm{~K}$, but only in one-third of samples, without antibody retrieving. One reason for the variability in the quality of fixation of samples with conventional method may be the large samples used by some authors. Microwave irradiation which penetrates all the samples, up to $1 \mathrm{~cm}^{3}$, may remove this variability. A short time of conventional fixation was therefore chosen for comparative reasons (Clark, 1985; Jeffrey et al.).

The development of microwave based immunohistochemistry protocols has relied on empirical observation, with little clear understanding of the mechanism involved. It has been shown that heat denaturizing of native protein secondary structure can be prevented by cross-linking with formaldehyde (Mason \& O’Leary, 1991). Therefore, formalin fixation may protect tissue antigens from the effects of microwave treatment, whereas native antibodies bound to tissue sections during immunostaining procedure are denatured by this treatment. However, this is clearly a complicated issue, as there are differential effects of microwave treatment in terms of denaturing fixed cytoplasmatic and nuclear antigens. Antigen retrieval is presumably a combination of improving antibody access to the antigen and possibly a partial breakdown of protein cross-linking that allows proteins sufficient freedom to assume conformations optimal for antibody binding. The immediate microenvironment of individual proteins, lipid versus macromolecular protein and nucleic acid, and the nature of secondary and tertiary protein structure may also be important factors in the differential effects of microwave oven heating on antigen recognition.

Thus, it was possible to conclude in this study that the results of two applied methods for antibody retrieval, presented an excellent methods for the use of Ki67 antibody in the immunohistochemical analysis. 
PITOL, D. L.; ISSA, J. P. M.; CAMACHO, E.; WOLGA, N. O.; CAETANO, F. H. \& LUNARDI, L. O. Fijación de tejidos de fetos de ratas por microondas: Análisis histológico e histoquímico. Int. J.Morphol., 25(4):695-701, 2007.

RESUMEN.El objetivo de este estudio fue evaluar la acción de las microondas en la fijación de los tejidos dérmico y cartilaginoso de fetos de ratas, usando para el análisis métodos histológico e inmunohistoquímico. Fue posible concluir en este estudio usando la rata como modelo experimental, que los dos métodos empleados para la recuperación antigénica representan excelentes medios para el uso del anticuerpo Ki67, en el análisis inmunohistoquímico.

PALABRAS CLAVE: Microondas; Rata; Análisis histológico e histoquímico; Fijación.

\section{REFERENCES}

Boon, M. E. \& Kok, L. P. Microwave cookbook of pathology. The art of microscopic visualization. Leiden, Coulomb Press, Leyden, 1987.

Boon, M. E. \& Kok, L. P. Microwave cookbook of pathology: The art of microscopic visualization. $2^{\text {nd }}$ ed. Coulomb Press Leyden, Leiden, 1988.

Boon, M. E. \& Kok, L. P. Theoretical and practical aspects of standartization of staining in diagnostic cytology. In Standartization and Quantification of Diagnostic Staining in Cytology (edited by Boon, M. E. \& Kok, L. P.), Leiden, Coulomb Press, Leyden, 1986.

Boon, M. E.; Marani, E.; Adriolo, P. J.; Steffelaar, J.W.; Bots, G.W. \& Kok, L. P. Obtaining paraffin sections of human brain in 24 hours using microwave irradiation. J. Clin. Pathol., 41:590-93, 1988.

Chew, E. C.; Riches, D. J.; Lam, T. K. \& Hou Chan, H. J. A fine structural study of microwaves fixation of tissues. Cell. Biol. Int. Rep., 7:135-9, 1983.

Clark, J. M. The organization of collagen in cryofractured rabbit articular: a scanning electron microscopic study. J. Orthop. Res., 3:17-29, 1985.

Clark, J. M. Variation of collagen fiber alignment in a joint surface: a scanning electron microscope study of the tibial plateau in dog, rabbit and man. J. Orthop. Res., 9:246$57,1991$.

Clarke, I. C. Articular cartilage: a review and scanning electron microscopy study. II. the territorial fibrillar architecture. J. Anat., 118:261-80, 1974.

Draenert, Y. \& Draenert, K. Ice crystal damage in freezedried articular cartilage studied by scanning electron microscopy. Scan. Electron. Microscop., 4:1799-804, 1982.
Drury, R. A. B. \& Wallington, E. A. Carleton's histological technique, $4^{\text {th }}$ ed. Oxford University Press, New York, 1967. pp. 33-46.

Echlin, P. Ice crystal damage and radiation effects in relation to microscopy and analysis at low temperatures. $J$. Microsc., 161:159-70, 1991.

Engfeldt, B.; Reinolt, F. P.; Hultenby, K.; Widholm, S. M.\& Müller, M. Ultrstructure of hypertrophic cartilage: histochemical procedures compared with high pressure freezing and freeze substitution. Calcif. Tissue. Int., 55: 274-80, 1994.

Gilmore R.S. \& Palfrey A. J. A histological study of human femoral condylar articular cartilage. J. Anat., 155:77$85,1987$.

Hopwood, D. Fixation and fixatives. In: Theory and practice of histological techniques, $2^{\text {nd }}$ ed. Bancroft, J. D. \& Steven A. eds. Churchill Livingstone, New York, 1982. pp. 20-39.

Hopwood, D.; Coghill, G.; Ramsay, J.; Milne, G. \& Kerr, M. Microwave fixation: Its potential for routine techniques, histochemistry, immunocytochemistry and electron microscopy. Histochem. J., 16:1171-91, 1984.

Hopwood, D.; Yeaman, G. \& Milne, G. Differentiating the effects of microwave and heat on tissue proteins and their crosslinking by formaldehyde. Histochem. J., 20:341-6, 1988.

Horobin, R. W. \& Flemming, L. "Trouble-shooting" microwave accelerated procedures in histological and histochemistry: understanding and dealing with artifacts, errors and hazards. Histochem. J., 22:371-6, 1990.

Hunziker, E. B.; Herrmann, W.; Schenck, R. K.; Müeller, M. \& Moor, H. Cartilage ultrastructure after high pressure 
freezing, freeze substitution, and low temperature embedding. I. Chondrocyte ultrastructure-implications for the theories of mineralization and vascular invasion. J. Cell. Biol., 98:267-76, 1984.

Hunziker, E. B. \& Schenck, R. K. Cartilage ultrastructure after high pressure freezing, freeze substitution, and low temperature embedding. II. Intercellular matrix ultrastructure- preservation of proteoglycans in their native state. J. Cell. Biol., 98:277-82, 1984.

Jeffrey, A. K.; Blunn, G. W.; Archer, C. W. \& Bentley, G. Three-dimensional collagen architecture in bovine articular cartilage. J. Bone. Joint. Surg. Br., 73:795-801, 1991.

Johnson, C. C. \& Guy, A.W. Non ionizing electromagnetic wave effects in biological materials and systems. Proc. IEEE., 60:692-718, 1972.

Jones, D. J. \& Stavinoha, W. B. Microwave inactivation as a tool for studying the neuropharmacology of cyclic nucleotides (ed. By G. C. Palmer). Urban \& Shwarzenberg, Baltimore, MD, 1979. pp.253-81.

Jurvelin, J.; Kuusela, T.; Heikkilä, R.; Pelttari, A.; Kiviranta, I.; Tammi, M. \& Helminen, H. J. Investigation of articular cartilage surface morphology with a semiquantitative scanning electron microscopic method. Acta. Anat., 116:302-22, 1983.

Keene, D. \& McDonald, K. The ultrastructure of the connective tissue matrix of skin and cartilage after high pressure freezing and freeze substitution. J. Histochem. Cytochem., 41:1141-53, 1993.

Kok, L.P. \& Boon, M.E. Microwaves for microscopy. Microscopy, 158:291-322, 1990b.

Leong, A. S.Y. Microwave irradiation in histophatology. Pathol. Ann., 23:213-33, 1988.

Login, G. R. \& Dvorak, A. M. Microwave energy fixation for electron microscopy. Am. J. Pathol., 120:230-43, 1985.

Login, G. R. \& Dvorak, A. M. Microwave fixation provides excellent preservation of tissue, cells and antigens for light and electron microscopy. Histochem. J., 20:37387,1988 .

Login, G. R. \& Dvorak, A. M. A review of rapid microwave fixation technology: its expanding niche in morphologic studies. Scanning, 15:58-66, 1993.
Login, G. R.; Stavinoha, W. B. \& Dvorak, A. M. Ultrafast microwave energy fixation for electron microscopy. $J$. Histochem. Cytochem., 34:381-7, 1986.

Mason, J. T. \& O’Leary, T. G. Effects of formaldehyde fixation on protein secondary structure: a calorimetric and infrared spectroscopic investigation. J. Histochem. Cytochem., 39:225-9, 1991.

Mayers, C. P. Histological fixation by microwave heating. J. Clin. Pathol., 23:273-5, 1970.

Nötzli, H. \& Clark, J. Microscopy of loaded articular cartilage preserved by freeze substitution. Trans $40^{\text {th }}$ Ann. Meet Orthopaedic. Res. Soc., 19:410-6, 1994.

Studer, D.; Michel, M.; Wohlwend, M.; Hunziker, E. B. \& Buschmann, M.D. Vitrivication of articular cartilage by high pressure freezing. J. Microsc., 179:321-2, 1995.

Visser, C. E.; Voute, A. B. E.; Oosting, J.; Boon, M.E. \& Kok, L. P. Microwave irradiation and cross linking of collagen. Biomaterials, 13:34-7, 1992.

Wickersheim, K.; Sun, M. \& Kamal, A. A small microwave E-field probe utilizing fibre optic thermometry. $J$. Microwave. Power. Electromagn. Energy, 25:141-8, 1990.

Correspondence to:

Dr. Dimitrius Leonardo Pitol

Faculdade de Odontologia de Ribeirão Preto - USP

Departamento de Morfologia, Estomatologia e Fisiologia

Av. Café $\mathrm{S} / \mathrm{N}$

CEP: $14040-904$

Ribeirão Preto, SP

BRAZIL

Phone: +55-16-36024095 Fax: +55-16-36330999

Email: dimipitol@yahoo.com.br

Received: 04-06-2007

Accepted: 17-08-2007 
